\title{
Functions of Collective Narratives in a Territorial Conflict. The Israeli-Palestinian Case
}

\author{
Josep Lobera ${ }^{1}$ \\ Cristóbal Torres-Albero ${ }^{2}$ \\ ${ }^{1}$ Assistant Professor. Department of Sociology, Autonomous University of Madrid (UAM). Madrid, Spain. \\ E-mail: josep.lobera@uam.es, ORCID: http:/ /orcid.org/0000-0002-0620-6312 \\ ${ }^{2}$ Professor. Department of Sociology, Autonomous University of Madrid (UAM). Madrid, Spain. \\ E-mail: cristobal.torres@uam.es, ORCID: http:/ /orcid.org/0000-0001-5630-9101 \\ Database: https://doi.org/10.7910/DVN/3556RW
}

\section{INTRODUCTION}

onflict resolution theorists argue that it is possible to transcend
conflicts if parties can be helped to explore, analyse, question and
reframe their positions and interests (e.g. Galtung, 1969, 1990; Lynch
and McGoldrick, 2010). Several obstacles to conflict resolution come
from tangible or non-tangible factors that can prevent or undermine
an agreement. Non-tangible factors are mainly related to conflicting
collective narratives, which are strongly connected to specific attitudes
and feelings towards the territory, the in-group and the out-group.
Collective narratives can be seen as intervening variables among a
series of other factors that create the conditions for a conflict to emerge
and to perpetuate. In the Israeli-Palestinian case, several authors have
identified the existence of conflicting narratives as one of the main
obstacles in conflict resolution (Rotberg, 2006; Dajani, 2006; Bar-Siman-
Tov, 2010; Auerbach, 2010).

Collective narratives are used to indicate a group's perception of a series of events. It implies that the story being told by one side is not identical to the story told by the other side. Narratives function "as the glue that enables human life to transcend the natural incoherence and discontinuity of the unruly everyday [...] by imposing a point of origin and an orientation toward closure" (Bamberg, De Fina and Schiffrin, 2007:5). Collective narratives and meta-narratives are one of 
the key functional resources in any conflict, allowing different parties to organize individuals around a common objective. In a protracted conflict, narratives often go beyond building Weltanschauungen [worldviews] to host Weltgefühle [feelings of the world], embracing several emotions such as distrust, hostility and fear ${ }^{1}$.

According to Kriesi (2012), grievances may be considered as exogenous shocks, engendering attitudinal and emotional consequences. Scholarship has given a growing attention since the late 1990s to the role of emotions in mobilization, and more broadly in all social action, as a provider of both motivation and goals (Jasper, 1998:397). Emotions and passion, as much as interests and ideologies, drive individuals to mobilize and join collective actions (Goodwin et al., 2004), and they were found to be a critical aspect of social conflict as they may energize mobilization (e.g. Montada and Schneider, 1989; Gould, 2010). Moreover, cognition and emotion are not mutually exclusive categories: emotion can and does operate within cognitive theories of narrative (Morden, 2016:7-8).

In this article, we aim to analyze the functions of collective and national narratives in the Israeli-Palestinian conflict, connecting the role of narratives to the construction of Weltanschauungen and Weltgefühle amongst supporters in either side of the conflict. By functions of a narrative we mean what narrative does for and to a social system and its individuals. Manifest functions are the objective consequences which are sought and recognized by participants in one context, and therefore are directly known by the social analyst. On the other hand, latent functions are those which exist but are not expected or recognizable by the agents, and can only be identified by scientific analysis (Merton, 1968).

In the following section we inter-relate the dynamics of national narratives and meta-narratives with the process of formation of national identity, with the aim of developing a conceptual framework of the functions of narratives in situations of territorial conflict. In the third section, we apply the resulting conceptual framework to the analysis of narratives to the Israeli-Palestinian case based on quantitative data. We also lay out the difficulties and methodological challenges of qualitative work with narratives in situations of conflict. In the fourth section, we identify the main functions of collective and national narratives in the Israeli-Palestinian conflict, putting special emphasis on those aspects not recognized and unforeseen by and for the agents. 
Finally, as a conclusion, we list the challenges faced by any attempt at conflict resolution in terms of the functions of narratives in conflict, and we suggest a possible approach to overcome these challenges.

\section{COLLECTIVE NARRATIVES AS A STRATEGIC RESOURCE IN TERRITORIAL CONFLICT}

Although the notion of a "borderless world" has been posited in several contexts, territory continues to be essential to the social and spatial configurations of modern statehood, as reflected not only in the concrete borders of the state, but also in the way in which territory acts as a foundation to the formation and construction of national identity (Newman, 1999:235). Territorial conflict is expressed as positional disputes concerning the location of international boundaries or a territorial status quo. It is widely known that this kind of dispute considerably increases the possibilities of armed conflict between groups and/or states (Huth and Allee, 2002:3). Change in the territorial status quo implies changes in the distribution of power, facilities and rewards which will directly affect different groups of people.

For an ethnic or national conflict to be sustained over time, leaders need material and symbolic resources (e.g. Horowitz, 2001; Wimmer, 2017). Without sufficient resources - both material and symbolic - they may face difficulties in keeping their allies and controlling their subordinates. Competition over the rights to a territory and claims to sovereignty are often based on collective narratives regarding time, location and national identity. Historical precedence or duration has been looked back on throughout history as a means of attaining recognition by the international community or justifying territorial expansion of a group holding a collective identity (Burghardt, 1973; Newman, 1999). All identity is constructed through time and narration (Ricoeur, 1987). Specifically, national identities are developed in a close link to specific spaces (territories) and times (narration of events).

As a result, hegemonic narratives which describe the history of the nation establish "the link between the nation and the territory that it claims, stress its uniqueness and unity, chart out its shared goals and mission, and cultivate the values and norms" by which the nation abides are inextricably created, tying the national identity to the territory (Kadman, 2015:33). In fact, national identity is itself a function of the attachment to the territory and the collective narrative displayed 
by the national group. Such attachment is often a result of a long historic process of socialization. Landscapes and past events are imbued with symbolic and mythical features as part of this socialization process. In this regard, national identity can be considered as a "socially constructed sameness" (Kunovich, 2009:574), a kind of sameness constructed through national narratives and meta-narratives. This process of "spatial socialization" - socializing individuals as members of a "territorially defined nationality" - instills a strong sense of identification with a given territory, including both material and symbolic elements, within its members (Kadman, 2015:33). As Blumer (1958) noted, the way in which a group builds its identity sets up a foundation for the conduct of its individuals. National narratives are not random, but respond to practical reasons of the social agents in conflict for power.

Meta-narrative is the framework which embraces, creates, and feeds collective narratives, which in turn strengthen and nourish the meta-narrative (Auerbach, 2010:102) ${ }^{2}$. National meta-narratives contain the ideological and moral foundation of the nation, as well as its "invented traditions" (Hobsbawm, 1988). Ultimately, national meta-narratives embody the ethos of the nation and the legitimacy of its very existence (Auerbach, 2010:102.). All narratives have a dramatic plot which develops over time with internal cohesion. This cohesion is achieved by means of a solid foundation based on the six elements of journalism: who, what, when, where, why and how (Auerbach, 2010).

A single event can be part of multiple, potentially overlapping and competing narratives because of the diverse experiences and perceptions of the event's participants (West, 2003). As Dajani (2006:2) notes, "the sharper the conflict, the wider the narratives diverge". Due to the important functions of narratives in the social dynamics of a conflict, each group of interest seeks to frame controversial events (Benford and Snow, 2000) according to their own narrative in order to pursue hegemony amongst their public. Narratives of conflict are time variant, as cultural products being edited and even created during conflicts. Once built and distributed, narratives work as vivid systems of meanings and values which give a sense of reality for the majority and reproduce the interests of the groups which have managed to impose their Weltanschauung and to propagate a certain Weltgefühl. 
It is important to stress that not only do narratives have negative effects, but they can also play a decisive role in peacebuilding. As West (2003:2) points out, after World War II, countries in Western Europe reconciled their previously highly conflicting and divergent national narratives. The rapprochement of narratives helped to strengthen European peace for several decades (Van Evera, 1991). Narratives in different groups, therefore, can draw near peace or conflict, and can be compatible or conflicting.

\section{Collective narratives and national identities}

Collective and national narratives are essential components of national identities and are strongly bound to national and supranational dynamics, either in times of stability or of territorial conflict. For a long time, a widespread idea in political theory claimed that the frontiers of a state should coincide with the territorial limits of a 'nation' - or of the group of people calling themselves so -, so that political power could be legitimated (Calhoun, 1997:69-70). However, many states have been built in territories containing several national groups. Linz (1993:355) offers an in-depth analysis of "the difficulties of making every nation a state and every state a nation".

Currently, several non-hegemonic national groups in multinational states manifest feelings of resentment. Coming from a collective perception of being relegated or having lesser rights than another group in a certain territory, resentment represents a major ingredient for dominant Weltgefühle in modern disputes ${ }^{3}$. This is apparent in several conflicts, such as in post-war Kosovo, where the Albanian political elite are struggling to "create a usable past and future identity" without basing it solely on anti-Serbian resentments (Ingimundarson, 2007:96). Narratives can contribute to generate and extend a feeling of resentment, bound with the sense of unfairness or injustice in past events. As Rotberg (2006:1) states, "history is the reservoir of resentment, the fount of blame" and legitimation; "without an acceptable recourse to the past, gaining legitimacy for rebellion and hostility, plus terror, is impossible". No modern-day cause attains an extensive following without such legitimation - "without an evocation of a hoary entitlement or a resurrected accusation of hurt".

Events and public expressions renew the importance of a narrative and increase the coherence of a group around it. Billig (1995) convincingly shows how nationhood and its meta-narratives are recurrently flagged 
in routine practices and everyday discourses, especially those in the mass media - even in the daily weather forecast. New communication media and information technologies play a key role, offering conflict leaders greater influence over larger groups, since today their discourse can reach a higher level of broadcasting, even in remote places, in very short periods of time. If endorsed by a critical mass of people, those discourses may become part of national narratives.

There is a well-developed theoretical framework dealing with the articulation of discursive elements in the construction of collective identities (Wodak, 1996; Van Dijk, 2011). De Cillia, Reisigl and Wodak (1999:160) distinguish four macro-strategies of discourse activity according to their dominant social function: (1) strategies of perpetuation, which try to maintain and reproduce already established groups, images, or other discursive artifacts; (2) destructive strategies, which are used to demolish an established situation or image; (3) strategies of transformation, which try to transform a status quo (or an aspect thereof) into something different; and (4) constructive strategies, which are used to construct something, e.g. discursively establishing groups ("us" and "them"), or an image of oneself, or an identity.

Social agents in conflict enunciate opposing discourses as to the preservation or transformation of a status quo, to build a social identity or to destroy it. Discourse activity is often tailored to the collective memory in order to be more effective. Thus, narratives are not only a reflection of a collective memory of the various parties in conflict, but a functional element in its dynamics.

In the Israeli-Palestinian case, conflicting narratives represent a major barrier in conflict resolution (Dajani, 2006; Bar-Tal and Salomon, 2006; Auerbach, 2010; Bar-Siman-Tov, 2010). At its heart, each side has created an ideological narrative which stresses its own bond to the land while downplaying or discarding the other side's claim (Kadman, 2015:37). As a result, each side sees itself as the victim of the conflict and the other side as the aggressor (Smooha, 2005:38). Both sides see themselves engaging in violence only in reaction to attacks started by a fundamentally and implacably violent enemy determined to destroy them (Haushofer, Biletzki and Kanwisher, 2010:17927). 
Econometric techniques allow one to empirically test the degree to which violence on each side occurs in response to aggression by the other side. Haushofer's, Biletzki's and Kanwisher's study shows that, when lethal and nonlethal forms of violence are considered, both Israeli and Palestinian violence reveal a pattern of retaliation. Over one half of Israelis and three-quarters of Palestinians think the other side seeks to take over their land; over two-thirds in both sides think that the other side is the one mainly to blame for the conflict; and three-quarters of Palestinian citizens of Israel and two-thirds of Israeli-Jews blame the other side for the 1948 war or the Nakba, respectively (Table 1). Ultimately, each side hurls endless charges against the other and claims it acts in the interest of security and survival.

\section{MEASURING CONFLICTING NARRATIVES}

To understand the impact of narratives on the conflict, it is necessary to investigate their acceptance and extension within each group. This can be approached empirically through data from public opinion surveys. Nevertheless, there are some methodological challenges - mainly those related to external validity - which must be considered. A first group of methodological challenges is related to low response rates, while a second group is related to the spiral of silence, social desirability and involvement bias.

As in many regions of the world, a growing 'survey fatigue' has been observed in recent years - today, the response rate in phone surveys in Israel is around only $25 \%$, and still declining. In addition, non-response rates are observed to be biased depending on political interest, age, secular versus Orthodox, and Jews versus Palestinians (Hermann, 2012). On the one hand, people of higher than average political interest are more likely to be present in the survey. This phenomenon is particularly intense among young Israelis, since they are significantly less willing to take part in surveys in general - and in political ones in particular - than older cohorts. On the other hand, secular populations are less willing to express their opinions than Orthodox/ultra-Orthodox people. This bias is particularly important due to the large divisions of opinion between secular and Orthodox/ultra-Orthodox sectors.

In addition, response rates among Palestinian citizens of Israel are significantly low, and even lower among women. As Hermann (2012) notes, Palestinian citizens of Israel are often worried that politically 
critical answers might be used against them under certain circumstances - e.g. when applying for civil service positions. Furthermore, the decrease in landline phone ownership in Israel has led to additional methodological challenges for phone surveys, similarly to other countries. This may result in biased estimates in landline telephone surveys, considering that landline ownership rises with age - peaking among people over 55 years old -, while mobile-only ownership increases among younger cohorts.

Data analysis has to take all of these biases into account. For our purposes, it is significant to note which opinions are more likely to be expressed in a survey, even though they may or may not have a lower presence in the population at large. Those opinions expressed more easily and openly in society are those which have more influence in the narrative dynamics within each group.

\section{Evidences of conflicting narratives}

There is reliable data from public opinion surveys with a long trajectory and recognized methodological soundness, such as the Guttman Center for Surveys database of public opinion surveys in Israel, the periodic surveys of the Palestinian Center for Policy and Survey Research, and the Index of Arab-Jewish Relations in Israel. We have identified the main collective narratives among the Jewish public and the Palestinians in Israel, as well as among Palestinians in Gaza and the West Bank from survey data collected by these centres. These collective narratives are connected to the dominant Weltanschauungen and Weltgefühle in each group.

The database of the Index of Arab-Jewish Relations in Israel presents some advantages for our purposes. Firstly, it provides greater regularity and length of the series of questions. Secondly, its questions are better suited to evaluating the "perceptions of others" and to contrasting the two main meta-narrative and the specific narratives around the conflict. However, this Index does not offer comparative data between Israeli Jews and Palestinians in the West Bank and Gaza. Either way, data from Jews and Palestinians in Israel present a clear polarization. This polarization shows us the direction of the opinion of Palestinians in the West Bank and Gaza, which will obviously be aimed at the extremes identified in the opinion surveys by Palestinian citizens of 
Israel. It is easy to infer that opinions in the West Bank and Gaza would be even more polarized - positively or negatively, depending on the question - than in the case of Palestinian citizens of Israel.

In short, survey data show two contradictory and incompatible narratives about historical events: the majority of Jews and Palestinians in Israel think that the other side holds most of the blame for the conflict and for the war of 1948 or the Nakba - over two thirds in both sides (Table 1). Conflicting narratives are deeply rooted in the different public opinion groups: they are fairly stable over time (Tables 1-2), and they possess significant magnitudes - over two thirds, in both cases (Tables 1-4).

Table 1

Opinion on the responsibility for the Israeli- Palestinian Conflict and al-Nakba (2003-2012)

[Strongly agree+Somewhat agree]:

$2004 \quad 2008 \quad 2012$

\subsection{Jews in Israel}

\begin{tabular}{|c|c|c|c|}
\hline $\begin{array}{l}\text { The Palestinians are the main guilty party for the protracted } \\
\text { conflict between Palestinians and the Jews }\end{array}$ & 68.4 & - & 68.6 \\
\hline $\begin{array}{l}\text { The Palestinians are the main guilty party for the disaster } \\
\text { which occurred to Palestinians in } 1948\end{array}$ & 65.8 & - & - \\
\hline \multicolumn{4}{|l|}{ 1.2 Palestinian citizens of Israel } \\
\hline $\begin{array}{l}\text { The Jews are the main guilty party for the protracted conflict } \\
\text { between the Palestinians and the Jews }\end{array}$ & 69.9 & - & 77.2 \\
\hline $\begin{array}{l}\text { The Jews are the main guilty party for the disaster which } \\
\text { occurred to the Palestinians in } 1948\end{array}$ & 75.4 & 74.9 & 82.2 \\
\hline
\end{tabular}

Source: Smooha (2005:116; 2010:18; 2013:164-208; 178-207).

These conflicting narratives go beyond building a Weltanschauung [a worldview] to host a Weltgefühl [feeling the world] in both public opinions, embracing emotions of mistrust, hostility, and fear. When that Weltanschauung points to the structural existence of unjust and threatening situations, its emotional extension increases, particularly feelings of fear and resentment. In the tables below, we can observe that two thirds of Israeli Jews refrain from entering Arab localities in Israel and over one half of them state that they are not ready to have an Arab neighbour (Table 2, Epigraph 2.1). On the other side of the narrative fabric, over two thirds of Palestinian citizens of Israel express fears of 
massive expulsions and the annexation of the Triangle to a Palestinian state against the will of its Palestinians residents. Furthermore, over $40 \%$ assert that they are not ready to have a Jewish neighbour (Table 2, Epigraph 2.2).

The proportion of Jews and Palestinians who see the members of the other group as not trustworthy and violent are high in both cases - e.g. $48 \%$ of Jews and $62 \%$ of Palestinians feel it is not possible to trust most members of the other group. Only a minority has friends from the "other group" - 15\% of Jews and 19\% of Palestinian citizens of Israel (Table 2). Although Palestinians have more interaction with Jews and are more exposed to the internal discrepancies in the Jewish population in comparison with the contact of Jews with Palestinians, their stereotypes and images are no less negative. Various scholars suggest that collective fear and distrust play an important role in establishing identity and maintaining collective behaviour (Bar-Tal, 2001; Petersen, 2002). Others have found that threatening and fear-producing experiences are connected to the rise of right-wing political conservatism (Jost et al., 2003) and can strengthen prejudices, ethnocentrism, and intolerance (Duckitt and Fisher, 2003).

Table 2

Fears, 2003-2012

[Strongly agree+Somewhat agree]:

2.1. Jews' Fears (Jews in Israel)

\begin{tabular}{lccc}
\hline & 2004 & 2008 & 2012 \\
\hline Refrain from entering Arab localities in Israel & 71.8 & 65.7 & 67.6 \\
Not ready to have an Arab neighbour & 52.5 & 46.9 & 52.4 \\
Have Arab friends and have been to their house & - & - & 15.4 \\
Arabs cannot be trusted & - & - & 48.3 \\
\hline
\end{tabular}


Table 2

Fears, 2003-2012 (cont.)

[Strongly agree+Somewhat agree]:

2004

2008

2012

2.2. Palestinians' Fears (Palestinian citizens of Israel)

\begin{tabular}{lccc}
\hline $\begin{array}{l}\text { Fear of the annexation of the Triangle to a Palestinian } \\
\text { state against the will of its Arab residents }\end{array}$ & 63.6 & 57.9 & 66.2 \\
$\begin{array}{l}\text { Fear of population transfer (mass expulsion) of some } \\
\text { Arab citizens }\end{array}$ & 63.5 & 56.6 & 68 \\
$\begin{array}{l}\text { Not ready to have a Jewish neighbour } \\
\text { Have Jewish friends and have been to their house }\end{array}$ & 25.7 & 47.3 & 44.6 \\
Jews cannot be trusted & - & - & 18.8 \\
\hline
\end{tabular}

Sources Smooha (2005:116; 2010:17-18, 22; 2013:164-179, 194-199).

This asymmetry of collective narratives between Palestinians and Jews is reflected in a deep asymmetry of opinions, perceptions and proposals for resolution (Tables 3-4). For example, only a minority in each group believes that the other group also has historical rights or even acknowledge the existence of the other side's main historical event. Palestinians and Jews also differ on the perception of the government of Israel and the idea of a Jewish-majority Israel. These groups further disagree on the right of Palestinian refugees to return to the land. 
Table 3

Perceptions of the conflict (2012)

[Strongly agree]:

Palestinian

citizens of Israel

\begin{tabular}{lcc}
\hline Arabs/Jews also have historical rights & 28.2 & 20.0 \\
$\begin{array}{l}\text { Believe the Holocaust happened } \\
\text { Believe the Nakba happened }\end{array}$ & - & 30.3 \\
$\begin{array}{l}\text { Zionism is colonialist and racist } \\
\begin{array}{l}\text { The Israeli government is also democratic } \\
\text { for Arabs }\end{array}\end{array}$ & 63.6 & 55.0 \\
$\begin{array}{l}\text { Israel should be a country controlled by } \\
\text { Jews }\end{array}$ & 86.0 & 20.3 \\
$\begin{array}{l}\text { Within the green line, there should be the } \\
\text { right for a Jewish-majority state to exist }\end{array}$ & 80.9 & 8.7 \\
$\begin{array}{l}\text { Palestinian refugees should be entitled to } \\
\text { return and to receive compensation }\end{array}$ & 9.5 & 7.8 \\
$\begin{array}{l}\text { Palestinians are Arabs which have settled in } \\
\text { Israel, which belongs to the Jewish people }\end{array}$ & 53.6 & - \\
\hline
\end{tabular}

Source: Smooha (2013: 169-205).

Table 4

Support for the use of violence

[Strongly support + support]:

West Bank Gaza Strip

(Palestinians)

79.0

the occupation in the Gaza Strip

Support the continuation of launching of rockets

from the Gaza Strip on Israeli cities and towns

until Israel agrees to end the siege and closure on

70.3

63.9

Gaza

Would support the return to the armed intifada and confrontations 
Table 4

Support for the use of violence (cont.)

[Strongly support + support]:

Jews in Israel

[2012] Operation Pillar of Defense was justified

The operation [2014 Protective Edge] in Gaza is just

95

Support the airstrikes on Gaza [2014 Protective Edge]

94

Protests against the IDF should be outlawed

74

Sources: Palestinian Public Opinion Poll, n. 55, 2015; The Peace Index, November 2012 and July 2014.

From this set of data, we can observe two opposite meta-narratives for which interpretations of current and historical events, as well as resolution proposals, are incompatible. The dominant Palestinian narrative presents Palestine as a nation continuously inhabited by their people for centuries until the Zionists expelled them and stole their land. In contrast, the core Israeli-Zionist narrative paints a picture of return from involuntary exile to the long-lost homeland to seek shelter from persecution (Kadman, 2015:37). After facing intense violence by Palestinians and surrounding Arab countries, they managed to prevail with higher moral standards than their adversaries and tohar haneshek, or the purity of arms (Shlaim, 1995), and they developed the country to benefit all of its inhabitants (Ben Gurion, 1948:1) by establishing a democratic Jewish state and leaving open the possibility of an independent Palestinian state (Goldschmidt and Davidson, 1991).

On the other hand, according to the main Palestinian narrative, the Jews are conquerors (Shlaim, 1995:287) or colonial settlers (Rodiason, 1973) who settled in Palestine, to which they had no rights. For Palestinians, the 1948 war is al-Nakba (The Catastrophe), in which more than 750,000 Palestinians were expelled from their homes (Pappé, 2006). Prolonged Israeli military occupation (Roberts, 1990; Sadi and AbuLughod, 2007:10) and its "systematic policy of confiscating Palestinian land, building Jewish settlements and destroying Palestinian homes serves as a continuous reminder of the original Nakba", in a constant renewal of the legitimacy of the Palestinian struggle (El-Sarraj, 2003). Palestinians see themselves as "fully entitled to resist the Israeli occupation" (El-Sarraj, 2003), given the establishment of an "inherently racist" and oppressive Zionist state which turned them into refugees (Ram, 1999:50-52). 
In the conflict, both Palestinian elites and Israeli elites have defined, on numerous occasions, their objectives in terms of denial or elimination of the opposite national territorial entity - see, e.g., statements of Israeli Prime Minister Netanyahu ${ }^{4}$, former Palestinian National Authority President Yasser Arafat ${ }^{5}$, or Hamas co-founder Mahmoud Al-Zahar6. Both national processes are seen as a threat in the narratives of the opposing group. In the Palestinian narrative, any aspect of the national and state-building processes of Israel are "processes of destruction, dispersion and dismantling" of the Palestinian society (Ehrlich, 1987:129). Likewise, many Israelis see Palestinian statehood as an inherent threat to the very existence of Israel (Shakdam, 2014). Thus, both parties feel that "it is a zero-sum conflict, not only with respect to territory, but, most importantly, with respect to national identity and national existence" (Kelman, 1999:588). The mere existence of the adversary territorial entity implies the renouncement to justice and fundamental rights, in the case of the Palestinian group, and to security and survival, in the Israeli case.

However, within both parts there are population segments among which hegemonic narratives are backed to a lesser degree (see Table 5). Among the Israeli Jewish population, the main axis of narratives is defined around the position on the conflict, on the Palestinian population and on the Jewish religious character and the State of Israel (Shafir and Peled, 2002; Smooha, 2010), while among the Arab population the axis is defined by the acceptance or not of the existence of the State of Israel, the right to return and the presence of religion in public life (Smooha, 2010). The attitudes and feelings of alienation toward Palestinians are significantly different among left-leaning and right-leaning Jewish publics (Table 5, Epigraph 5.1), in some cases showing differences of more than 50 percentage points. Likewise, in the case of the Palestinian public in Israel, there are differences of up to 30 percentage points between people voting Jewish parties and Arab parties in the Knesset (Table 5, Epigraph 5.2). Smooha (2010:25-28) found that specific drivers of support for coexistence among Palestinians are living or not in a mixed city, religion and having or not a refugee relative, whereas, among Jews, drivers are religiousness, political ideology and having had or not personal suffering from Palestinians. 
Table 5

Subgroups of opinion. Differences between Jewish and

Palestinian groups in percentage feeling alienation

5.1. Differences between Jewish groups in percentage feeling alienation

\begin{tabular}{lcccc}
\hline & $\begin{array}{c}\text { Public figures } \\
\text { on the left }\end{array}$ & $\begin{array}{c}\text { Public on the } \\
\text { left }\end{array}$ & $\begin{array}{c}\text { Public figures } \\
\text { on the right }\end{array}$ & $\begin{array}{c}\text { Public on } \\
\text { the right }\end{array}$ \\
\hline $\begin{array}{l}\text { Refrain from entering } \\
\text { Arab localities in Israel }\end{array}$ & 3.2 & 57.2 & 34.4 & 78.7 \\
$\begin{array}{l}\text { Not ready to have an } \\
\text { Arab neighbour }\end{array}$ & 0.0 & 18.9 & 53.1 & 74.3 \\
Feel distant from Arabs & 19.4 & 60.8 & 56.3 & 82.6 \\
\hline
\end{tabular}

5.2. Differences in percentage feeling alienation between Palestinian groups in Israel

\begin{tabular}{lcccc}
\hline & $\begin{array}{c}\text { Non-establish- } \\
\text { ment public } \\
\text { figures }\end{array}$ & $\begin{array}{c}\text { Establishment } \\
\text { public figures }\end{array}$ & $\begin{array}{c}\text { Voters for } \\
\text { Arab parties }\end{array}$ & $\begin{array}{c}\text { Voters for Jew- } \\
\text { ish parties }\end{array}$ \\
\hline $\begin{array}{l}\text { As an Israeli citizen I feel } \\
\text { alien and rejected }\end{array}$ & 87.8 & 25.0 & 63.8 & 33.1 \\
Feel distant from Jews & 46.9 & 19.4 & 57.7 & 38.5 \\
Feel most Jews are racist & 61.2 & 33.3 & 50.8 & 38.5 \\
\hline Source: Smooha (2005:72; 84). & & &
\end{tabular}

Despite internal differences, data shows that, within each group, hegemonic narratives are further divided into two main groups, Jewish and Palestinian. Narratives which include elements of both positions are the minority on both sides. They explicitly voice narratives which might be termed conciliatory: $22 \%$ of Palestinians and $27.9 \%$ of Jews in Israel do not think that the other side is the main guilty party for the protracted conflict between Palestinians and Jews, and that the other side also has historic rights $-28.2 \%$ of Jews and $20 \%$ of Palestinians (Table 3). These narratives, despite being a minority in this conflict, are essential in the dynamics of its resolution. Resolving the conflict requires a transformation of the conflicting narratives which prolong it, as well as fostering conciliatory narratives. 


\section{FUNCTIONS OF THE NARRATIVES IN THE ISRAELI-PALESTINIAN CONFLICT}

Social action is conditioned by collective narratives. Therefore, these are likely to be used or promoted by a wide range of agents in a territorial conflict in order to pursue their interests. We have identified ten main social functions, combining cognitive and emotional elements, based on the collective narratives at the core of the Israeli-Palestinian conflict:

Main narratives tend to function as binary elements. One side is right while the other is wrong (Table 1). Narratives are essential functional elements of the constructive strategies of discourse, allowing the recognition of groups in conflict ("us" and "them") (Cf. Avnery, 2015). National groups are imagined in the sense that their members "will never know most of their fellow-members, meet them, or even hear of them" (Anderson, 1983:15). National narratives, therefore, are the backbone of national identity and of the feeling of belonging to the group.

Once groups are established, narratives create unity. Collective narratives are intrinsically linked to a feeling of unity, to a matrix of belonging, and thus they can avert the anguish of "separateness" of individuals, especially in contexts of insecurity and distrust ${ }^{7}$. The main narratives allow strangers to unite and build trust within a single group (see Tables 1, 3, 4). In this regard, the use of a narrative which includes people to unity for the simple reason of sharing an identity is extremely effective. Uniformity and coordination of group behaviour emerge from this process, boosting both social solidarity and social control. Participating in a binary narrative implies benefits for individuals, especially when both the binary identity and the conflict are intense. No citizen wants to feel excluded from his or her neighbours, not only from direct neighbours but also from the imagined community with which they may interact with in the future.

As part of the same process, narratives allow separation; they can generate distrust of the 'enemy'. They create a "community of enemies" - even though they are likewise unknown individuals - (Tables 1 and 2). In doing so, narratives limit the extent to which received notions can be altered by new perceptions. Indeed, group members inculcated 
by their narrative anticipate the worst from their adversaries and react accordingly. Thus, peace-oriented gestures may often be rejected as political manoeuvres rather than genuine efforts.

Narratives enable the interpretation of past events. Narratives provide the means to explain the "recall" of past events which were not experienced by the participants in the present conflict, since they provide a coherent interpretation of the conflict's origin and how it has unfolded over time. Israeli commentator Meron Benvenisti (1995:200) notes that national myths, made up of a mixture of real and legendary events, are "the building-blocks from which a society constructs its collective self-image' and, once absorbed, 'become truer than reality itself'" (see Table 1). Past events remain a large reservoir of resentment, a connection with the unfairness or injustice in current events. Although in some conflicts important narratives regarding past events may change over time, in the Israeli-Palestinian case they have mostly remained static for decades (see Tables 1-2).

Narratives enable the interpretation of current events. New information is selectively received, encoded, and interpreted according to previous schemata of the narratives. Information consistent with the narrative is self-affirming, while the "other narrative" is perceived as propaganda. Past narratives - which include past abuses - are often preserved by the media to develop similar discursive elements in the present which impact the interpretation of current events as a prolongation of the past (Tables 3-4). The main agents in the conflict supply the motives behind actions, framed within the national narrative, to present their behaviour as coherent and readable by their followers.

Main narratives act as motivational frames. In a protracted conflict, collective narratives help organize individuals around a common objective, from participation in the use of force (army, militia etc.) to financial contributions in support of the conflict, through legitimation of the conflict by means of their vote in elections. They allow followers to mobilize, urged by the nature of their collective meanings to act in the group's interest (Bar-Tal and Staub, 1997; Rotberg, 2006). Furthermore, in the conflict dynamics, silent participation is required - an implicit support of the position of the main leaders of the group (Tables 1-3). Without the participation of most of their group's members, leaders cannot sustain an intense intervention of their group in the conflict. On 
the other hand, as seen in Table 5, in each group there will be collectives which are more or less able to be mobilized depending on the specific narrative which is appealed to after the mobilization.

Main narratives contribute to justifying acts of the in-group towards the opponent, allowing people to engage in extreme violence (Apter, 1996; Bar-Tal and Salomon, 2006). In all societies, violence against another human being, especially extreme violence, is morally and legally reproached. In a territorial conflict, narratives allow the use of extreme violence (Table 5), in all of its force, resolving "feelings of dissonance, guilt and shame for group members" (Bar-Tal and Salomon, 2006:35) by means of the attribution of one's own immoral behaviour entirely to parties and forces external to them. In this vein, collective narratives can be seen as one of key sources of Galtung's "cultural violence" in a territorial conflict, alongside ideology, religion, art or science. According to Galtung (1990:292), cultural violence makes direct and structural violence look or feel "right", or at least not wrong, changing the "moral color" of an act from "red/wrong" to "green/right", or at least to "yellow/acceptable". This function is the key for group leaders. Without it, the capacity to damage the enemy with different forms of violence would be compromised. At the same time - and, generally speaking, unintendedly -, the use of violence often reinforces the narrative of the other group and its feeling of resentment, which leads to the strengthening of the spiral of conflict, providing the opposing narrative with greater intensity.

Main narratives reinforce international alliances and the moral character of their commitment ('Hamas' Deif', 2015; 'CNN Poll', 2014)' The Israeli-Palestinian conflict is one of the most internationalized conflicts in history. Narratives serve to permanently preserve the international ties of the parties and justify the moral character of the intervention to the public opinion of the countries involved (Tables 1, 3, 4). In order to be effective, narratives of conflict have to be made compatible with broader narratives of international relations. Thus, the purpose of preserving international alliances through narratives requires adjustments in time to adapt them to any potential changes on an international level (e.g. changes in the perception of legitimacy of different types of violence and social organization). This point can open windows of opportunity for the resolution of the conflict, but it can also - as in the case of Israel-Palestine - contribute to a greater complexity in its 
resolution, since the narratives of either group's international allies can grow further apart and oppose over time, dragging the narratives of the conflict with them.

Narratives convey a sacred character to the group and, by extension, to the conflict and the actions linked to it. Different expressions of the conflict which have become sacred for the participants through national narratives and meta-narratives, such as the area of "Jerusalem" or "Al-Quds" (Landman, 2010), or the issue of the Palestinian refugees (haq al-'awda) (Bar-Siman-Tov, 2010), as reflected in Table 3. Landman (2010) identifies several protected values and their capacity to hurdle conflict resolution. The sacralisation of central aspects of the conflict imbue the conflict itself with sacred character - and, by extension, some of its agents, such as heroes, martyrs, istishhad, jihad etc. -, as well as the historical destination of the group itself $f^{8}$. Thus, the narratives of the conflict can make up an Ersatz-religion, as Linz (2004) put it: a secular ideology which can really serve the purpose of legitimizing the actions linked to the conflict equally or better than the political use of a religion. Also, the sacralisation of the conflict poses significant difficulties for its resolution and can generate unanticipated consequences when adversaries treat contested issues as sacred values, as shown by the experiments of Ginges and others (2007) .

The use of hegemonic narratives reinforces the leadership position of elites. Elites identify predominant narratives and project them in their discourses in order to legitimize their policies and their leadership within the group. Frequently, elites justify their leadership as a historical or sacred mission for the good of their people ${ }^{10,11}$. In this respect, elites often use self-legitimizing, charismatic discourses to bolster them in the struggle for internal leadership and lessen their accountability to the electorate.

This array of functions is generally latent and not manifest, that is to say, they are not recognized by those who use or promote them. Furthermore, their use also brings about unintended consequences, and may aggravate the conflict beyond their initial intended use. For instance, when a narrative is put forward to unify the group itself it may also unify the opposing group and reinforce their own meta-narrative. The greater the social bonding within a system, the greater this social mechanism of unintended consequences. Territorial conflicts especially the Israeli-Palestinian conflict - involve many agents, some 
of them in third countries, whose actions and reactions branch out and interact with each other. In situations of territorial dispute, there is a predominance of forms of behavioural interdependence and, in the long term, evolutionary interdependence. Both forms are characterized by agents whose actions are based on complex considerations, since a strategy requires knowledge not only of the interests of the other party but also of their strategy - which normally includes assumptions about one's strategy (Coleman, 1990:30). This is why actions in a situation of territorial dispute frequently lead to the generation of unintended consequences to a greater extent than in situations which only involve forms of structural interdependence.

\section{CONCLUSIONS}

In this study, we identified ten social functions of collective narratives based in the Israeli-Palestinian conflict. Many agents - especially political and social elites on both sides - are strategically connected to the use of narratives. The transformation of hegemonic narratives and the emergence of new ones will imply a progressive repositioning of a wide range of agents in the conflict with respect to the previous functions: new redefinitions of the binary identity of the groups, of the unconditional unit, the unjustifiable enemy, new frameworks for the interpretation of past and current events, new considerations regarding the justification of the use of violence, changes in citizens' capacity for mobilization, in international bonds and strategies, redefinitions of what is sacred and profane within the conflict, as well as a repositioning of leaderships within groups. It is very unlikely that all agents - both national and international - affected by these changes in position will be easily willing to transform their role in the conflict, transforming and adopting new narratives. These agents - specially leaders - hold a position of power within the conflict of the current narratives, and the use of the new non-conflicting narratives does not offer them any guarantee of maintaining that position. Therefore, it would be necessary to consider how new narratives can affect these agents and enable their repositioning in a new scenario, in which currently conflicting narratives become compatible.

Dealing with conflicting narratives is an intrinsic aspect of any attempt at conflict resolution. National narratives need to be transformed to a large degree, preferably with the coordination of both groups. In our case study, the gap between the conflicting narratives of both sides 
is vast and cannot be bridged at this stage. Conflicting narratives are deeply rooted in both groups: they are fairly stable over time (Tables 1-2), and they possess significant magnitudes - over two thirds in both cases (Tables 1-4). Both worldviews and feelings of the world are highly conflicting and can hinder any peace process, preventing each side from reaching out to the other. Yet there continues to be hope as "the Arab-Israeli conflict, which at first has a zero-sum, protracted nature, has changed over time through effective conflict management that has made conflict reduction and even resolution possible" (Bar-Siman-Tov, 2010). This transformation will not occur overnight, but rather as a long process, requiring fundamental changes in both sides' narratives. Although a process of transformation of narratives in conflict is required for its resolution, both groups will face resistance associated with the functionality of the narratives during this process.

Despite the specificities of each case, national narratives and meta-narratives represent one of the key resources for a wide range of agents in conflict, because of their important social functions. Readers can make inferences about extrapolating the findings to other settings. Understanding these functions will help identify barriers or potential incentive losses experienced by several agents in a peace process due to the transformation of conflicting narratives. Assisting agents to overcome these barriers may positively contribute to peacebuilding efforts in territorial conflicts.

(Received on October 20, 2018)

(Resubmitted on September 15, 2019)

(Accepted on May 11, 2020)

\section{NOTES}

1. The term Weltanschaunng refers to the wide and specific conception of the world of a well differentiated social group. It incorporates moral and cognitive elements, indicating what the world is and how the group should behave towards it. See Mannheim (1952). We employ the term Weltgefühl as a concept associated with Weltanschauung, and as an extension thereof in the emotional sphere. This term, originally employed by Eugen Fink in 1931, has seen little development in the literature. A similar concept suggested by Bar-Tal (2001) is "collective emotional orientation", which refers to the characterizing tendency of a society to express a particular emotion.

2. Lyotard (1984) noted that, even though in our time we can observe increasing skepticism towards grand meta-narratives, national meta-narratives still affect people deeply. 
3. Max Scheler's work on the Nietzschian concept of resentment points out that, instead of being a consequence of social and political inequality in itself, the phenomenon develops as a trait of those societies where there was an expectation of equal rights. In Scheler's (1961) words, "ressentiment must therefore be strongest in a society like ours, where approximately equal rights (political and otherwise) or formal social equality, publicly recognized, go hand in hand with wide factual differences in power, property, and education".

4. "There cannot be a situation, under any agreement, in which we relinquish security control of the territory west of the River Jordan. [...] If we were to pull out of Judea and Samaria, like they tell us to, there'd be a possibility of thousands of tunnels. [...] At present we have a problem with the territory called Gaza". Giving the West Bank back to Palestinians would "create another 20 Gazas", Prime Minister Netanyahu said. As editor Horovitz writes in the Times of Israel, "[Netanyahu] made explicitly clear that he could never, ever, countenance a fully sovereign Palestinian state in the West Bank" (Netanyahu: Gaza Conflict, 2014).

5 "The goal of our struggle is the end of Israel, and there can be no compromises or mediators ... We don't want peace we want victory. Peace for us means Israel's destruction and nothing else" (The Endless Intifada, 1980).

6 "Our ultimate plan is [to have] Palestine in its entirety. I say this loud and clear so that nobody will accuse me of employing political tactics" (Goldberg, 2014).

7. From various perspectives, such as the analysis of the psychology of the masses (Reich, 1933) and conformity experiments (Asch, 1951), the tendency of humans to agree with their group of reference and the effects of peer pressure has been shown. From an individual perspective, Fromm (1956:8) points to the experience of "separateness" as "the source of all anxiety".

8. For instance, the Shi'i notion of Mahdism offers a teleological narrative well suited to legitimize charismatic authority (Filiu, 2009), as seen in the case of Hassan Nasrallah.

9. A series of experiments carried out by Ginges et al. (2007) indicate that violent opposition to compromise over issues considered sacred is increased by offering material incentives to compromise but decreased when adversaries make symbolic compromises over their own sacred values. This also shows that conflicts may backfire when adversaries treat contested issues as sacred values.

10. Yasser Arafat: "I swear to God, I will see [the Palestinian state], whether as a martyr or alive. Please, God, give me the honor of becoming a martyr in the fight for Jerusalem" ("Arafat Willing", 2002).

11. Benjamin Netanyahu: "It's my sacred duty as the prime minister to make Israel's case" (Baker, 2015), about his speech in the US Congress. Later he added in his Twitter account: "I am leaving for Washington on a fateful, even historic mission. I am the emissary of all Israelis, even those who disagree with me" (Netanyahu, 2015). 


\section{REFERENCES}

ANDERSON, Benedict. (1983), Imagined communities: reflections on the origin and spread of nationalism. London: Verso.

APTER, David E. (1996), The legitimization of violence. Basingstoke: Palgrave.

"ARAFAT WILLING to die for Palestinian statehood". (2002), USA Today [online]. January 21 [16-11-2020]. Available at: http://usatoday30.usatoday.com/news/world/2002/01/21/ arafat-martyr.htm

ASCH, Solomon E. (1951), "Effects of group pressure on the modification and distortion of judgments". In: H. Guetzkow (ed.), Groups, leadership and men. Pittsburgh: Carnegie Press, pp. 295-303.

AUERBACH, Yehudith. (2010), "National narratives in a conflict of identity". In: Y. BarSiman-Tov (ed.), Barriers to peace in the Israeli-Palestinian conflict. Study number: 406. Jerusalem: Institute for Israel Studies, pp. 99-134.

AVNERY, Uri. (2015), "For arabs everywhere, zionism is the synonym of Evil". Al-Jazeerah, CCUN [online]. 2015, February 9 [15-02-2018]. Available at: http:/ / www.aljazeerah.info/ Opinion\%20Editorials/2015/February/9\%20o/For\%20Arabs\%20Everywhere,\%20Zionism \%20Is\%20the\%20Synonym\%20of\%20Evil\%20By\%20Uri\%20Avnery.htm

BAKER, Luke. (2015), "As address to U.S. Congress nears, Netanyahu treads a thinning line", Reuters [online]. February 26 [20-11-2020]. Available at: https:/ /www.reuters. com/article/uk-israel-netanyahu-congress-idUKKBNOLU1ZG20150226

BAMBERG, Michael; DE FINA, Anna; SCHIFFRIN, Deborah. (2007), Selves and identities in narrative and discourse. Amsterdam: John Benjamins.

BAR-SIMAN-TOV, Yaacov. (2010), "Barriers to Conflict Resolution". In: Y. Bar-Siman-Tov (ed.), Barriers to peace in the Israeli-Palestinian Conflict. Study number: 406. Jerusalem: Institute for Israel Studies, p. 178.

BAR-TAL, Daniel. (2001), "Why does fear override hope in societies engulfed by intractable conflict, as it does in the Israeli Society?". Political Psychology, vol. 22, nº 3, pp. 601-627.

; SALOMON, Gavriel. (2006), "Israeli-Jewish narratives of the Israeli-Palestinian conflict: evolution, contents, functions, and consequences". In: R. I. Rotberg (ed.), Israeli and Palestinian narratives of conflict. Bloomington: Indiana University Press, pp. 19-46.

BAR-TAL, Daniel; STAUB, Ervin. (1997), Patriotism in the lives of individuals and nations. Nashville: Nelson-Hall.

BEN-GURION, David. (1948), "The declaration of the establishment of the State of Israel". Official Gazette, vol. 1, n 1, p.1.

BENFORD, Robert D.; SNOW, David A. (2000), "Framing processes and social movements: an overview and assessment". Annual Review of Sociology, vol. 26, n 1, pp. 611-639.

BENVENISTI, Meron. (1995), Intimate enemies: jews and arabs in a Shared Land. Oakland: University of California Press.

BILLIG, Michael. (1995), Banal Nationalism. London: Sage. 
BLUMER, Herbert. (1958), "Race prejudice as a sense of group position”. The Pacific Sociological Review, vol. 1, n 1, pp. 3-7.

BURGHARDT, Andrew. (1973), "The bases of territorial claims". Geographical Review, $\mathrm{n}^{\circ} 63, \mathrm{pp} .225-245$.

CALHOUN, Craig J. (1997), Nationalism. Buckingham: Open University Press.

"CNN POLL: Majority of Americans side with Israel in Gaza fighting". (2014), CNN [online]. July 21 [01-02-2018]. Available at: http:/ / politicalticker.blogs.cnn.com/2014/07/21/ cnn-poll-americans-clearly-side-with-israel-in-gaza-fighting

COLEMAN, James S. (1994), Foundations of Social Theory. Cambridge: Harvard University Press.

DAJANI, Mohammed S. (2006), "Palestinians: contested narratives". CCCB Papers, Barcelona, CCCB.

DE CILLIA, Rudolf; REISIGL, Martin; WODAK, Ruth. (1999), "The discursive construction of national identities". Discourse \& Society, vol. 10, n 2, pp. 149-173.

DUCKITT, John; FISHER, Kirstin. (2003), "The impact of social threat on worldview and ideological attitudes". Political Psychology, vol. 24, n 1, pp. 199-222.

EHRLICH, Avishai. (1987), "Israel: conflict, war, and social change". In: M. Shaw; C. Creighton (eds.), The sociology of war and peace. New York: Sheridan House, pp. 121-142.

EL-SARRAJ, Eyad. (2003), "On violence and resistance". The Palestine-Israel Journal [online], vol. 10, nº 1. [11-11-2020]. Available at: http://www.pij.org/details.php?id=78.

FILIU, Jean Pierre. (2009), "The return of political mahdism". Current Trends in Islamist Ideology, vol. 8, pp. 26-38.

FROMM, Eric. (1956), The art of loving. New York: Harper and Brothers.

GALTUNG, Johan. (1969), "Violence, peace, and peace research". Journal of Peace Research, vol. $6, n^{\circ} 3$, pp. 167-191.

. (1990), “Cultural Violence”. Journal of Peace Research, vol. 27, n 3, pp. 291-305.

GINGES, Jeremy et al. (2007), "Sacred bounds on rational resolution of violent political conflict". Proceedings of the National Academy of Sciences, vol. 104, $n^{\circ}$ 18, pp. 7357-7360.

GOLDBERG, Jefrey. (2014), "What would Hamas do if it could do whatever it wanted?". The Atlantic [online]. August 4 [20-11-2020]. Available at: https:/ / www.theatlantic.com/ international/archive/2014/08/what-would-hamas-do-if-it-could-do-whatever-it-wanted/375545/

GOLDSCHMIDT, Arthur; DAVIDSON, Lawrence. (1991), A concise history of the middle east. Boulder: Westview Press.

GOODWIN, Jeff.; JASPER; James M.; POLLETTA, Francesca. (2004), “Emotional dimensions of social movements". In: D. A. Snow; S. A. Soule; H. Kriesi (eds.), The blackwell companion to social movements. New Jersey: John Wiley \& Sons, pp. 413-432.

GOULD, Deborah. (2010), “On affect and protest”. In: J. Staiger; A. Cvetkovich; A. Reynolds (eds.), Political emotions. London: Routledge, pp. 32-58. 


\section{Josep Lobera and Cristóbal Torres-Albero}

“HAMAS' Deif reportedly tells Hezbollah's Nasrallah: Let's unite against Zionist enemy". (2015), The Jerusalem Post [online]. 2015, January 22 [01-06-2018]. Available at: http:// www.jpost.com/Arab-Israeli-Conflict/Hamas-Deif-tells-Hezbollahs-Nasrallah-Lets-unite-against-Zionist-enemy-388543

HAUSHOFER, Johannes; BILETZKI, Anat; KANWISHER, Nancy. (2010), “Both sides retaliate in the Israeli-Palestinian conflict". Proceedings of the National Academy of Sciences, vol. 107, nº 42, pp. 17927-17932.

HERMANN, Tamar. (2012), Measuring Israeli democracy, 2011: epistemological, methodological, and ethical dilemmas. Paper presented at the WZB, Berlin, January 23.

HOBSBAWM, Eric. (1988), The age of revolution 1789-1848. London: Abacus Books.

HOROWITZ, Donald L. (2001), Ethnic groups in conflict. Oakland: University of California Press.

HUTH, Paul K.; ALLEE, Todd L. (2002), The democratic peace and territorial conflict in the twentieth century. Cambridge: Cambridge University Press.

INGIMUNDARSON, Valur. (2007), "The politics of memory and the reconstruction of Albanian National Identity in Postwar Kosovo". History \& Memory, vol. 19, nº 1, pp. 95-123.

JASPER, James M. (1998), "The emotions of protest: affective and reactive emotions in and around social movements". Sociological Forum, vol. 13, n 3, pp. 397-424.

JOST, John T. et al. (2003), "Political conservatism and motivated social cognition". Psychological Bulletin, vol. 129, $\mathrm{n}^{\circ} 3$, pp. 339-375.

KADMAN, Noga. (2015), Erased from space and consciousness: Israel and the depopulated Palestinian Villages of 1948. Bloomington: Indiana University Press.

KELMAN, Herbert C. (1999), "The interdependence of Israeli and Palestinian identities: the role of the other in existential conflicts". Journal of Social Issues, vol. 55, nº 3, pp. 581-600.

KRIESI, Hanspeter. (2012), “The political consequences of the financial and economic crisis in Europe: Electoral Punishment and Popular Protest". Swiss Political Science Review, vol. $18, \mathrm{n}^{\circ} 4$, pp. 518-22.

KUNOVICH, Robert M. (2009), "The Sources and Consequences of National Identification". American Sociological Review, vol. 74, $\mathrm{n}^{\circ}$ 4, pp. 573-593.

LANDMAN, Shiri. (2010), "Barriers to peace: protected values in the Israeli-Palestinian conflict". In: Y. Bar-Siman-Tov (ed.), Barriers to peace in the Israeli-Palestinian Conflict. Study number: 406. Jerusalem: Institute for Israel Studies, pp. 135-177.

LINZ, Juan J. (1993), "State Building and Nation Building". European Review, vol. 1, nº 4, pp. 355-369.

. (2004), "The religious use of politics and/or the political use of religion: Ersatz ideology versus Ersatz Religion". In: H. Maier (ed.), Concepts for the comparison of dictatorships, vol. 1. London, Routledge, pp. 102-119.

LYNCH, Jake; MCGOLDRICK, Annabel. (2010), "A global standard for reporting conflict and peace". In: R. L. Keeble; J. Tulloch; F. Zollmann (eds.), Peace journalism, war and conflict resolution. New York: Peter Lang, pp. 87-104. 
LYOTARD, Jean François. (1984), The postmodern condition: a report on knowledge. Minneapolis: University of Minnesota Press.

MANNHEIM, K. (1952), “On the interpretations of Weltanschauung”. In: Essays in the Sociology of Knowledge. New York: Oxford University Press, pp. 33-83.

MERTON, Robert K. (1968), Social theory and social structure. New York: The Free Press.

MONTADA, Leo; SCHNEIDER, Angela. (1989), "Justice and emotional reactions to the disadvantaged". Social Justice Research, vol. 3, n 4, pp. 313-344.

MORDEN, Michael. (2016), "Anatomy of the national myth: archetypes and narrative in the study of nationalism". Nations and Nationalism, vol. 22, n 3, pp. 447-464.

“NETANYAHU: Gaza conflict proves Israel can't relinquish control of West Bank". (2014), Times of Israel [online]. July 11 [06-05-2018]. Available at: http:/ /www.timesofisrael.com/netanyahu-gaza-conflict-proves-israel-cant-relinquish-control-of-westbank/\#ixzz38QoYPszr

NETANYAHU, B. (2015), "I am leaving for Washington on a fateful, even historic mission. I am the emissary of all Israelis, even those who disagree with me". Twitter [online]. March 1 [16-10-2020]. Available at: http:/ / twitter.com/netanyahu/status/572030363641495552

NEWMAN, David. (1999), "Real spaces, symbolic spaces: interrelated notions of territory in the Arab-Israeli conflict". In: P. F. Diehl (ed.), A road map to war: territorial dimensions of international conflict. Nashville: Vanderbilt University Press, pp. 3-34.

PAPPÉ, Ilan. (2006), “The 1948 ethnic cleansing of Palestine". Journal of Palestine Studies, vol. $36, n^{\circ} 1$, pp. 6-20.

PETERSEN, Roger D. (2002), Understanding ethnic violence. Cambridge: Cambridge University Press.

RAM, Uri. (1999), “The colonization perspective in Israeli Sociology”. In: I. Pappé (ed.), The Israel/Palestine question. London: Routledge, pp. 49-71.

REICH, Wilhelm. (1933), Die Massenpsychologie des Faschismus. New York: Farrar, Straus and Giroux.

RICOEUR, Paul. (1987), Time and Narrative III. Chicago: The University of Chicago Press.

ROBERTS, Adam. (1990), "Prolonged military occupation: the Israeli-Occupied Territories since 1967". American Journal of International Law, vol. 84, nº 1, pp. 44-103.

RODIASON, Maxine. (1973), Israel: a colonial settlers state. New York: Pathfinder.

ROTBERG, Robert I. (2006), “Building legitimacy through narrative”. In: R. I. Rotberg (ed.), Israeli and Palestinian narratives of conflict. Bloomington: Indiana University Press, pp. 1-18.

SADI, Ahmad H.; ABU-LUGHOD, Lila. (2007), "Introduction”. In: A. H. Sadi; L. Abu-Lughod (eds.), Nakba: Palestine, 1948, and the claims of memory. New York: Columbia University Press, pp. 1-24.

SHAFIR, Gershon; PELED, Yoav. (2002), Being Israeli: the dynamics of multiple citizenship. Cambridge: Cambridge University Press. 
Josep Lobera and Cristóbal Torres-Albero

SHAKDAM, Catherine. (2014), "Why Palestinian statehood poses such a threat to Israel", Mint Press News [online]. December 29 [20-02-2018]. Available at: http://www.mintpressnews.com/palestinian-statehood-poses-threat-israel/200249/

SCHELER, Max. (1961), Ressentiment. New York: The Free Press of Glencoe.

SHLAIM, Avi. (1995), “The debate about 1948". International Journal of Middle East Studies, vol. $27, n^{\circ} 3$, pp. 287-304.

SMOOHA, Sammy. (2005), Index of Arab-Jewish Relations in Israel 2004. Haifa: The JewishArab Center, University of Haifa.

. (2010), Index of Arab-Jewish Relations in Israel 2003-2009. Haifa, The Jewish-Arab Center, University of Haifa.

“THE ENDLESS Intifada". (2001), The Washington Times [online]. August, 30 [20-11-2020]. Available at: https:/ / www.washingtontimes.com/news/2001/aug/30/20010830-025029-8628r/

VAN DIJK, Teun A. (2011), Discourse studies: a multidisciplinary introduction. London: Sage.

VAN EVERA, Steven. (1991), "Primed for peace: Europe after the Cold War". International Security, vol. 15, n 3, pp. 7-57.

WEST, Deborah L. (2003), Myth and narrative in the Israeli-Palestinian conflict. WPF Report number: 34. Cambridge: John F. Kennedy School of Government, Harvard University.

WIMMER, Andreas. (2017), "Power and pride: national identity and ethnopolitical inequality around the world". World Politics, vol. 69, n 4, pp. 605-639.

WODAK, Ruth. (1996), Disorders in discourse. New York: Longman. 


\section{RESUMO}

\section{As Funções das Narrativas Coletivas em um Conflito Territorial: O Caso Israel-Palestina}

As diversas narrativas de um conflito desempenham um papel central em seu desenvolvimento. Elas são não só um reflexo da memória coletiva das diferentes partes em conflito, mas também um elemento funcional de sua dinâmica. No caso do conflito entre Israel e Palestina, os dados mostram que as principais narrativas de cada lado são razoavelmente estáveis ao longo do tempo, e apresentam uma significativa magnitude - mais de dois terços do público em ambos os casos. Este artigo analisa o uso de narrativas nas dinâmicas do conflito, o que afeta tanto a dimensão cognitiva quanto a emocional da visão de mundo do público de ambos os lados. Abordamos dez funções principais das narrativas coletivas envolvidas no conflito. Discutimos que, apesar de uma transformação dessas narrativas ser necessária para a resolução do conflito, ambos os grupos enfrentarão resistência, associada com a funcionalidade das narrativas durante esse processo.

Palavras-chave: narrativas nacionais; discurso; emoções; resolução de conflito; violência cultural

\section{ABSTRACT \\ Functions of Collective Narratives in a Territorial Conflict. The Palestinian-Israeli Case}

The various narratives of a conflict play a central role in its development. Not only are they a reflection of the collective memory of the various parties in conflict, but also a functional element in its dynamics. In the case of the Palestinian-Israeli conflict, data show that each side's main narratives are fairly stable over time, and they possess significant magnitudes - over two thirds of their publics, in both cases. This article analyses the use of narratives in the dynamics of the conflict, which affects both the cognitive and emotional dimensions of the public's worldview on both sides. We draw ten main functions of collective narratives in the conflict. We discuss that, although a transformation of narratives in the conflict is required for its resolution, both groups will face resistance associated with the functionality of the narratives during this process.

Keywords: National narratives; discourse; emotions; conflict resolution; cultural violence 


\section{RÉSUMÉ}

Fonctions des Récits Collectifs dans un Conflit Territorial: Le Cas Israélo-Palestinien

Les différents récits d'un conflit jouent un rôle central dans son développement. Non seulement ils sont le reflet de la mémoire collective des différentes parties en conflit, mais aussi un élément fonctionnel dans la dynamique de celui-ci. Dans le cas du conflit israélo-palestinien, les données montrent que les principaux récits de chaque côté sont assez stables dans le temps et qu'ils possèdent une ampleur significative - plus de deux tiers de leur public, dans les deux cas. Ce article analyse l'utilisation des récits dans la dynamique du conflit, qui affecte à la fois les dimensions cognitives et émotionnelles de la vision du monde du public des deux côtés. On dessine dix fonctions principales des récits collectifs dans le conflit et on discute du fait que, bien qu'une transformation des récits en conflit soit nécessaire pour sa résolution, les deux groupes feront face à une résistance associée à la fonctionnalité des récits au cours de ce processus.

Mots-clés: récits nationaux; discours; émotions; résolution de conflit; violence culturelle

\section{RESUMEN}

Funciones de las Narrativas Colectivas en el Conflicto Territorial. El caso Palestino-Israelí

Las distintas narrativas del conflicto juegan un papel central en su desarrollo. No son solamente un reflejo de la memoria colectiva de las diferentes partes, sino un elemento funcional en sus dinámicas. En el caso del conflicto Palestino-Israelí, las principales narrativas de cada lado son bastante estables a lo largo del tiempo y tienen magnitudes significativas - de más de dos tercios de sus públicos, en ambos casos. Este artículo analiza el uso de narrativas en las dinámicas del conflicto, las cuales afectan tanto a la dimensión cognitiva como a la emocional de la cosmovisión del público de ambos lados. Mostramos las principales funciones de las narrativas colectivas en el conflicto y defendemos que, a pesar de que la transformación de estas narrativas es necesaria para su resolución, ambos grupos se enfrentan a la resistencia asociada con la funcionalidad de las narrativas durante este proceso.

Palabras clave: narrativas nacionales; discurso; emociones; resolución de conflictos; violencia cultural 